\title{
ANALISIS PENGARUH VARIASI PERSENTASE RAGI (Saccharomyces cerevisiae) DAN WAKTU PADA PROSES FERMENTASI DALAM PEMANFAATAN DUCKWEED (Lemna minor) SEBAGAI BIOETANOL
}

\author{
Oleh: \\ Siti Khodijah', Ahmad Abtokhi
}

\begin{abstract}
ABSTRAK: Salah satu alternatif dalam mendukung ketersediaan sumber daya energi terbarukan adalah dengan memanfaatkan sumber dari non fosil seperti bioetanol. Bioetanol merupakan etanol yang dibuat dari biomass yang mengandung komponen pati (karbohidrat) atau selulosa yang selanjutnya di fermentasi menggunakan bantuan mikroorganisme (Sacharomyces cerevisiae). Karbohidrat yang digunakan pada penelitian ini berasal dari Lemna minor (Duckweed). Penelitian ini bertujuan membuat bioetanol dari Lemna minor dengan variasi penambahan ragi dan lamanya waktu fermentasi. Kemudian bioetanol ini ditentukan kadar etanol dan densitasnya serta mengetahui hubungan antara keduanya. Produksi bioetanol telah dilakukan melalui proses konversi karbohidrat menjadi gula (glukosa) dengan hidrolisis asam $(\mathrm{HCl})$. Hidrolisat yang diperoleh selanjutnya dilakukan fermentasi dengan menambahkan yeast atau ragi sehingga diperoleh bioetanol. Variabel yang digunakan adalah perubahan massa ragi $5 \%, 15 \%$, dan $25 \%$ serta lama fermentasi 5, 6, dan 7 hari . Hasil penelitian menunjukkan lama fermentasi dan persentase ragi mempengaruhi kadar etanol. Nilai kadar etanol optimum diperoleh presentase ragi 25\% dengan lama fermentasi 7 hari sebesar $3.81 \%$ dengan density optimum sebesar $0.9438 \mathrm{gr} / \mathrm{cm}^{3}$, Hubungan nilai densitas berbanding terbalik dengan peningkatan kadar etanol.
\end{abstract}

Kata kunci: Persentase ragi; waktu fermentasi; Lemna minor.

\begin{abstract}
One alternative in favor of the availability of renewable energy resources is to utilize non-fossil sources such as bioethanol. Bioethanol is ethanol made from biomass component containing starch (carbohydrate) or cellulose. Furthermer it is fermented using microorganisms (Sacharomyces cerevisiae). In this study Lemna minor (Duckweed) was used to produce carbohydrates. This study aims is to make bioethanol from Lemna Minor with percentage of yeast and length of fermentation time in variation. It is then determined the ethanol value, density and the relation between them. Bioethanol production was conducted through the process of converting carbohydrates into sugar (glucose) by acid hydrolysis $(\mathrm{HCl})$. Hydrolysates were then fermented by adding yeast to obtain bioethanol. The used variables were yeast mass 5\%,15\%, and 25\% and fermentation time 5, 6, and 7 days. The results pointed out that the percentage of yeast and fermentation time affect the levels of ethanol. The optimum ethanol value obtained by $25 \%$ ethanol with 7 days fermentation lenght was $3.81 \%$. While optimum density was $0.9438 \mathrm{~g} / \mathrm{cm}^{3}$. The relation between ethanol value and density are inversely proportional.
\end{abstract}

Keyword: Percentage of yeast; fermentation time; Lemna minor.

\footnotetext{
${ }^{1}$ Mahasiswa Jurusan Fisika, Fakultas Sains dan Teknologi, UIN Maliki Malang. E-mail: claradijez@yahoo.co.id

${ }^{2}$ Staf Pengajar pada Jurusan Fisika, Fakultas Sains dan Teknologi UIN Maliki Malang
} 


\section{PENDAHULUAN}

Krisis energi merupakan masalah utama yang sampai saat ini belum dapat dipecahkan oleh negara berkembang termasuk Indonesia. Salah satu yang mendasari terjadinya kelangkaan energi adalah pemakaian kendaraan bermotor berbahan bakar bensin yang dari tahun ke tahun semakin meningkat.

Pengembangan bioenergi seperti bioetanol dari biomassa sebagai sumber bahan baku yang dapat diperbarui merupakan satu alternatif yang memiliki nilai positif dari aspek sosial dan lingkungan Bioetanol dihasilkan melalui proses fermentasi gula sederhana dengan bantuan mikroorganisme. Mikroorganisme utama yang digunakan dalam fermentasi etanol adalah ragi (1). Produksi bioetanol dari tanaman yang mengandung pati atau karbohidrat, dilakukan melalui proses konversi karbohidrat menjadi gula glukosa) (2). Beberapa metode diantaranya dengan hidrolisis katalis asam, glukosa yang dihasilkan selanjutnya dilakukan proses fermentasi atau peragian dengan menambahkan yeast atau ragi sehingga diperoleh bioetanol.

Peningkatan efisiensi produksi bioetanol dapat dicapai dengan memilih bahan baku yang tepat, optimasi praperlakuan bahan baku dan tahap fermentasi etanol, serta pemanfaatan produk samping secara optimal. Optimasi dalam fermentasi etanol dapat dilakukan dengan mengendalikan parameter utama pada tahap tesebut (3). Adapun beberapa faktor yang mempengaruhi proses fermentasi diantaranya Kondisi-kondisi yang mempengaruhi fermentasi etanol antara lain kandungan protein dari media, volume starter dan waktu pada proses fermentasi.

Lama fermentasi pada proses produksi Bioetanol sangat mempengaruhi kadar bioetanol yang dihasilkan. Semakin lama waktu fermentasi maka semakin tinggi kadar bioetanol yang dihasilkan. Jika Bioetanol yang terkandung di dalam substrat tinggi maka hal ini justru akan berpengaruh buruk terhadap pertumbuhan Saccharomyces cerevisiae. Oleh Karena itu dibutuhkan lama fermentasi yang tepat untuk proses fermentasi bioetanol agar didapatkan kadar etanol dalam jumlah yang tinggi (4).

Saccharomyces cerevisiae adalah salah satu spesies khamir yang memiliki daya konversi gula menjadi etanol sangat tinggi. Mikroba ini biasanya dikenal dengan baker's yeast dan metabolismenya telah dipelajari dengan baik. Produk metabolit utama adalah etanol, CO2 dan air, sedangkan beberapa produk lain dihasilkan dalam jumlah sedikit. Khamir ini bersifat fakultatif anaerobik. Saccharomyces cerevisiae memerlukan suhu 30 ${ }^{0} \mathrm{C}$ dan $\mathrm{pH} 4,0-4,5$ agar dapat tumbuh dengan baik. Selama proses fermentasi akan timbul panas. Bila tidak dilakukan pendinginan, suhu akan terus meningkat sehubungan proses fermentasi terhambat (5).

Salah satu alternatif Sumber Daya Alam (SDA) yang dapat digunakan sebagai bahan bioetanol adalah memanfaatkan pati yang terkandung dalam duckweed (Lemna minor). Lemna minor merupakan gulma air (tumbuhan yang sebagian atau seluruh daur hidupnya berada di tempat yang berair), sehingga tidak di perjual belikan dan kurang di manfaatkan oleh masyarakat. Pada tumbuhan ini memiliki kandungan protein $17-36,5 \%$ dan karbohidrat 32,1-42,9\% dari $100 \%$ bahan kering (6). Sehingga apabila dijadikan bahan 
baku pembuatan bioetanol sangat layak dari dari segi ketersediaanya,karena kandungan pati dalam lemma minor ini dapat dikonversi menjadi bioetanol.

Penelitian ini bertujuan untuk Mengetahui pengaruh variasi persentasi ragi dan lama waktu fermentasi terhadap proses pembuatan bioetanol dari Lemna minor serta mengetahui hubungan densitas bioetanol dari Lemna minor terhadap kadar bioetanol yang didapatkan. Data yang digunakan dalam penelitian ini adalah hasil dari eksperimen pada saat pengujian menggunakan alat. Adapun analisa data menggunakan microsoft excel untuk membuat grafik dan uji anova dalam menganalisis data. Penelitian ini dilakukan pada bulan Februari 2014, di laboratorium fisika material dan kimia anorganik Universitas Islam Negeri Maulana Malik Ibrahim Malang dan Laboratorium Kimia Politeknik Negeri Malang.

Penelitian diawali dengan ditimbang 50 gram Lemna minor bentuk bubuk untuk dilarutkan dalam $5 \mathrm{ml}$ HCL $0.1 \mathrm{~N}$ dan $500 \mathrm{ml}$ aquades. Kemudian diaduk menggunakan hot plate magnetic stirer dengan lama waktu 90 menit dengan suhu $70{ }^{\circ} \mathrm{C}$ berupa Filtrat, selanjutnya diukur keasaman dengan mencapai ukuran $5 \mathrm{pH}$.Terlebih dahulu dilakukan pembuatan starter Saccharomyces cerevisiae dari ragi roti (soft instans) yang dicampur dengan aquades dan gula yang telah dihomogenkan dan di autoclave selama 15 menit, setelah itu starter diinkubasi selama 8 jam, selanjutnya filtrat diberi perlakuan variasi persentase ragi $5 \%, 15 \%$, dan $25 \%$ dari volume filtrat $(120 \mathrm{ml}$ filtrat) dan variasi waktu 5,6, dan 7 hari. Hasil dari filtrat yang telah difermentasi didestilasi kemudian diuji dengan GC untuk mengetahui kadar etanol, uji densitas dan dianalisa.

\section{HASIL DAN PEMBAHASAN}

\section{A. Pengaruh Waktu Fermentasi dan Persentase Ragi Saccharomyces serevisiae Terhadap Karakteristik Fisika Uji Densitas Bioetanol}

Bioetanol hasil fermentasi yang sudah di destilasi dilakukan Penentuan densitas etanol dengan menimbang piknometer kosong, kemudian dimasukkan larutan destilat kedalam piknometer dan dihitung dengan menggunakan persaman di bawah ini.

$$
r=\mathrm{m} / \mathrm{Vp}
$$

dimana:

$$
\begin{aligned}
& \mathrm{m}=\text { massa }(\text { piknometer }+ \text { sampel })-\text { massa piknometer kosong } \\
& \mathrm{Vp}=\text { Volume piknometer }(60 \mathrm{ml})
\end{aligned}
$$

Dari data yang diperoleh, dibuat grafik hubungan waktu fermentasi dan persentase ragi terhahap Uji Densitas yang disajikan pada gambar 1. Dari gambar 1 dapat diketahui bahwa penambahan ragi dan waktu fermentasi pada uji densitas yang paling optimum pada perlakuan persentase ragi $25 \%$ dan waktu selama 7 hari di peroleh nilai $0.9438\left(\mathrm{gr} / \mathrm{cm}^{3}\right)$. Berdasarkan dari gambar 1 tersebut diolah menggunakan analisa statistik two ways analysys of variance (ANOVA). Adapun data yang telah diolah menggunakan two ways anova hasil dari uji statistik Two Ways ANOVA didapatkan nilai sig. Waktu dan Persentase $(.000)<0.05$ sehingga kita bisa menyatakan bahwa $\mathrm{H}_{0}$ ditolak $\mathrm{H}_{1}$ diterima. Dengan demikian adanya perbedaan waktu fermentasi dan persentase ragi pada pembuatan bioetanol mempengaruhi besar kecilnya nilai densitas yang dihasilkan. Hal ini dikarenakan lama fermentasi memiliki pengaruh terhadap density alkohol yang diuji dimana pengaruh 
tersebut berupa suatu penurunan dalam nilai density seiring bertambahnya waktu, bahwa semakin lama fermentasi aktivitas mikrobia mengalami pertumbuhan dengan berkembang biak semakin banyak, sehingga dengan semakin meningkatnya jumlah mikroba maka semakin banyak pula karbohidrat yang terurai menjadi alkohol. Dengan meningkatnya jumlah alkohol ini maka berat atau densitas daripada campuran alkohol-air akan semakin rendah. Semakin tinggi persentase ragi maka semakin rendah nilai density. Hal ini karena ragi Saccharomyces cerevisiae merubah glukosa menjadi etanol, dimana jika ragi yang diberikan banyak maka etanol yang dihasilkan juga akan semakin banyak dan begitu juga sebaliknya, sehingga densitasnya akan semakin rendah.

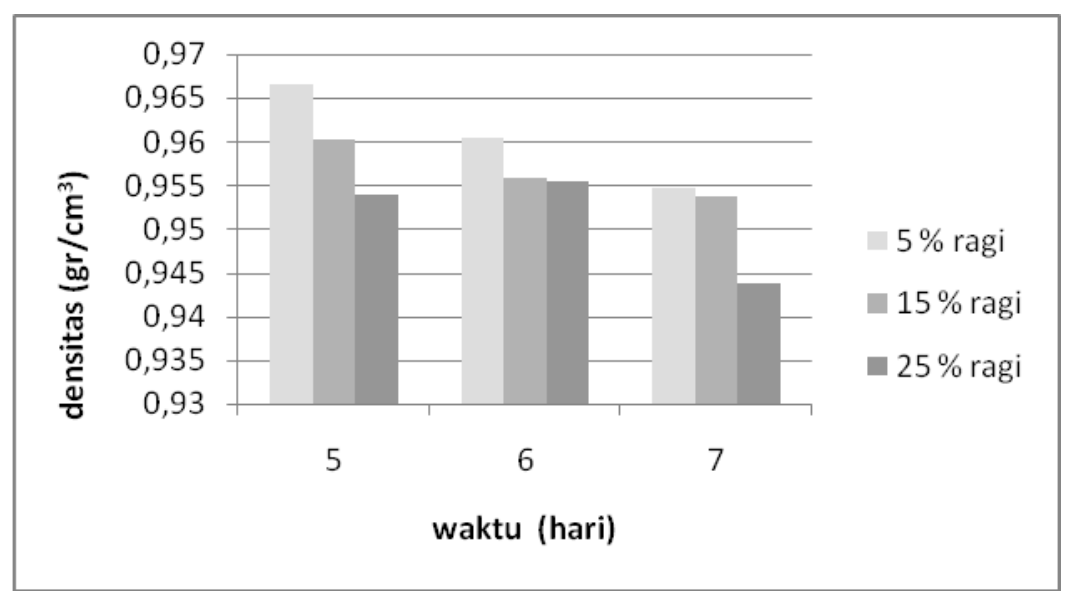

Gambar 1. Grafik Hubungan waktu fermentasi dan prosentase ragi terhahap Uji Densitas

\section{B. Pengaruh Persentase Ragi Saccharomyces cerevisiae dan Waktu Fermentasi Terhadap Uji Kadar Etanol.}

Pengujian kadar etanol dengan GC (Gas Cromotoghraphy) dilakukan di Laboratorium Kimia Politeknik Negeri Malang kadar etanol dari Lemna minor ini menggunakan metode GC (Gas Cromotoghraphy), dimana metode ini dapat digunakan untuk menguji kadar etanol karena dapat memisahkan campuran zat-zat organik.

Dari data yang diperoleh, dibuat grafik hubungan waktu fermentasi dan prosentase ragi terhahap kadar etanol. Gambar 2 menunjukkan bahwa penambahan ragi dan waktu fermentasi pada kadar etanol yang paling baik pada perlakuan prosentase ragi $25 \%$ dan waktu selama 7 hari di peroleh kadar etanol 3,81\%.). Berdasarkan dari gambar 2 tersebut diolah menggunakan analisa statistik two ways analysys of variance (ANOVA). Adapun data yang telah diolah menggunakan two ways anova hasil dari uji statistik Two Ways ANOVA didapatkan nilai sig. Waktu $(0.651)>0.05$ sehingga $\mathrm{H}_{0}$ diterima $\mathrm{H}_{1}$ ditolak. Adanya perbedaan lama fermentasi pada pembuatan bioetanol tidak ada pengaruh secara signifikan terhadap kadar etanol yang dihasilkan. Hal ini kemungkinan disebabkan jarak antara satu waktu ke waktu lain terlalu pendek dengan interval waktu fermentasi 1 hari. Karena menurut Amerine (1982) lama fermentasi berlangsung dua sampai tiga minggu dan ditandai dengan tidak diproduksinya $\mathrm{CO}_{2}$. 


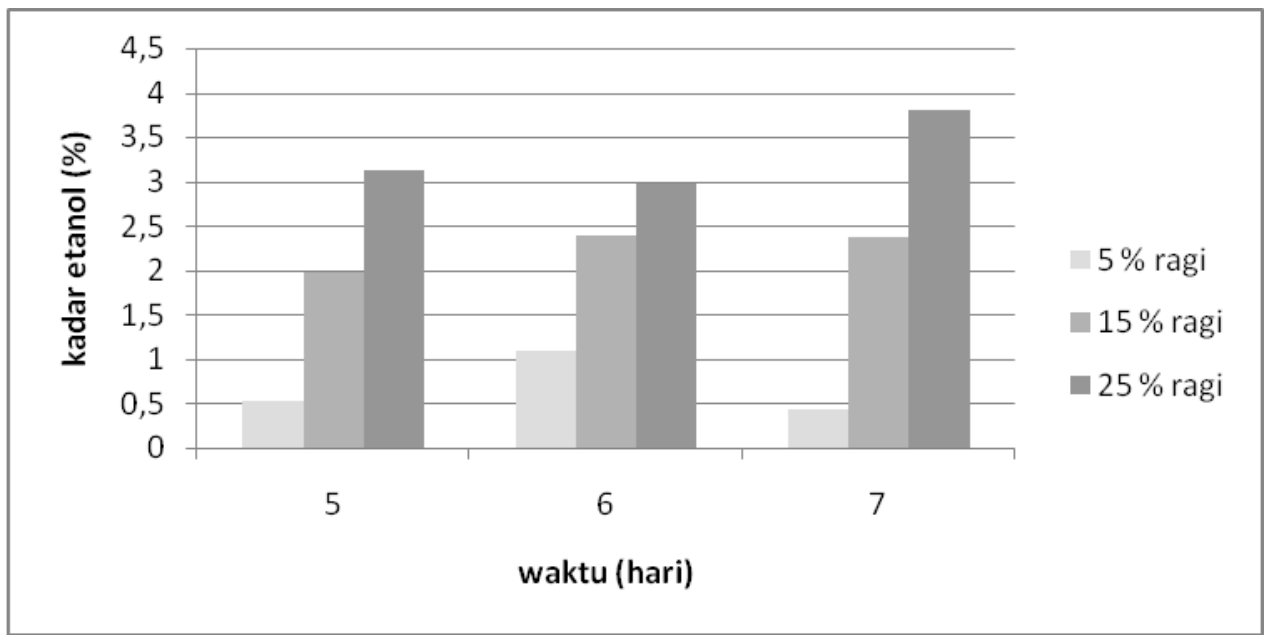

Gambar 2. Grafik Hubungan waktu fermentasi dan presentase ragi terhahap Uji kadar etanol

Untuk nilai sig. Persentase ragi (.000) > 0.05 sehingga $\mathrm{H}_{0}$ ditolak $\mathrm{H}_{1}$ diterima. Adanya perbedaan persentase ragi pada pembuatan bioetanol ada pengaruh secara signifikan terhadap kadar etanol yang dihasilkan. Karena dengan penambahan starter $25 \%$ dihasilkan kadar etanol yang lebih besar dibandingkan dengan starter 5\% dan 15\% hal ini disebabkan Saccharomyces cerevisiae tumbuh dengan drastis dan persediaan nutrien yang menunjang petumbuhan Saccharomyces cerevisiae masih banyak seiring penambahan starter lebih besar sehingga bakteri yang merubah glukosa menjadi etanol semakin besar, proses ini akan terhenti jika kadar alkohol tidak dapat ditolerir oleh mikroba.

\section{Hubungan Densitas Dengan Kadar Etanol}

Nilai kadar etanol sangat berpengaruh terhadap nilai densitas yang disebabkan oleh penguapan etanol. Semakin tinggi nilai kadar etanol maka rantai karbon semakin panjang dan mengakibatkan rantai carbon mudah terputus dengan bertambahnya suhu. Ketika suhu $70{ }^{0} \mathrm{C}$ etanol mengalami penguapan dengan berkurangnya nilai densitas.

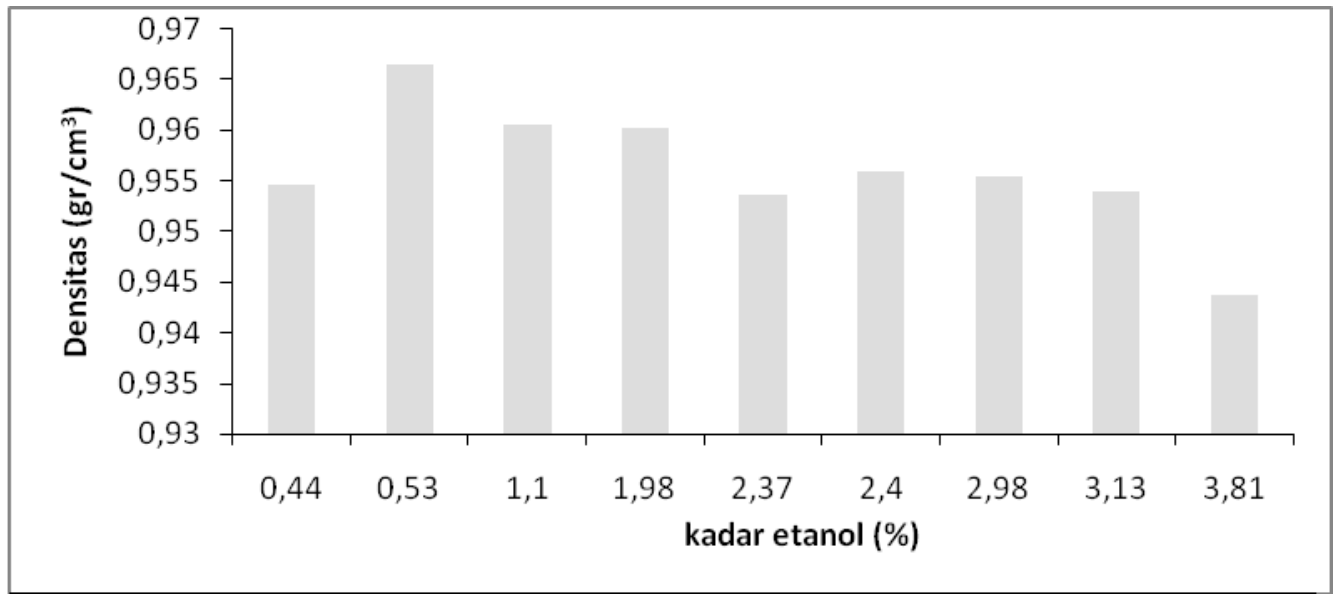

Gambar 3. Grafik hubungan densitas terhadap nilai kadar etanol

Gambar 3 menunjukkan bahwa nilai densitas berbanding terbalik dengan kadar etanol yang dihasilkan. Semakin rendah densitas etanol menunjukkan kadar etanol semakin tinggi. Nilai densitas $0,943 \mathrm{gr} / \mathrm{cm}^{3}$ diperoleh kadar etanol optimum sebesar 3,81\%. 


\section{KESIMPULAN}

Berdasarkan hasil analisis data diperoleh kesimpulan sebagai berikut:

1. Penambahan variasi persentase ragi Saccharomyces cerevisiae mempengaruhi densitas dan nilai kadar etanol, yakni untuk ragi $25 \%$ memiliki kadar etanol optimumnya sebesar $3.81 \%$ dengan lama fermentasi 7 hari.

2. Lamanya variasi waktu fermentasi juga mempengaruhi hasil akhir dari bioetanol. Waktu fermentasi 7 hari menghasilkan nilai densitas paling optimum sebesar 0,9438 $\mathrm{gr} / \mathrm{cm}^{3}$ pada persentase ragi $25 \%$.

3. Hubungan densitas dengan kadar etanol berbanding terbalik, semakin rendah nilai densitas etanol menunjukkan kadar etanol semakin tinggi, disebabkan karena massa jenis etanol adalah lebih kecil dibandingkan air.

\section{DAFTAR PUSTAKA}

(1) G M Walker. Bioethanol science and technology of fuel alcohol. BookBoon. com. Frederiksberg: Denmark; 2010.

(2) Marques, S et al. Conversion of Recycled Paper Sludge to Ethanol by SHF and SSF Using Pichia Stipitis. Portugal: Departemento de Biotecnologia, INETI, Estrada do Paco do Lumiar 22, 1649-038 Lisboa; 2006.

(3) M L Shuler, F Kargi. Bioprocess Engineering Basic Concept. USA: Prentice Hall Inc. 1992.

(4) Azizah N. Pengaruh Lama Fermentasi Terhadap Kadar Alkohol, pH, dan Produksi Gas Pada Proses Fermentasi Bioetanol dari Whey dengan Subsitusi Kulit Nanas. Jurnal Aplikasi Teknologi Pangan UNDIP;2012 Vol.1 No.2.

(5) Oura E. Reaction Product of Yeast Fermentation. H. Dellweg(ed). Biotechnology. New York : Academic Press; 1983. Volume III

(6) Rusooff LL. E W Blakeney, DD Culley. A potential Source of Protein and Amino acids. Duckweeds (Lemneceae family): J. Agrie. Food Chem; 1980 .28 : 848- 850 